\title{
MICROBIOLOGICAL QUALITY ASSESSMENT OF RAW COWS MILK IN PESHAWAR DISTRICT
}

\author{
Aziza Alam¹, Ambreen Akhtar², Rubeena Gul', Rozina Rehman' \\ Department of Community Medicine, Khyber Medical College, Peshawar - Pakstan \\ Department of Community Medicine, Khyber Girls Medical College, Peshawar - Pakstan
}

\begin{abstract}
Objective: To study the microbial analysis of raw cow's milk collected from selling points of Peshawar.
\end{abstract}

Materials and methods: A total of 80 aseptically raw milk samples were collected by multistage sampling technique from four towns of Peshawar in sterile glass bottles and stored in ice containers for laboratory analysis at Agriculture University Peshawar. Microbial analysis was performed on plate count and samples were screened for staph aureus, E.coli spp, and salmonella spp. The microbiological load was tested and the data were analyzed by Statistical Package for Social Sciences (SPSS) version 20.

Results: The microbial analysis of milk revealed contamination of milk and the most prevalent bacteria was Escherichia coli (26.2\%) and the least prevalent was Salmonella spp (3.75\%).

Conclusion: Although the presence of E.coli spp, staph spp, and Salmonella spp. indicate that the milk is contaminated but found that the total bacterial count was within the permissible limit. If not controlled in time will lead to public health issues. This highlights an urgent need to adopt good sanitary practices and monitoring of milk from production to distribution by the health authorities.

Key Words: Microbial analysis, raw cow's milk, E.coli spp, staph spp

This article may be cited as: Alam A, Akhtar A, Gul R, Rehman R. Microbiological quality assessment of raw cows milk in Peshawar district. J Med Sci 2021 July;29(3):112-115

\section{INTRODUCTION}

The farm animals industry in a country like Pakistan is facing a lot of challenges like poorly developed animal husbandry and diseases that are affecting the quality of milk being produced. Bacterial contamination of milk is a common problem faced by the dairy industry, especially in developing countries. When the animal is diseased, bacteria can gain access to the milk from the primary source, as in the case of mastitic milk. Secondary bacterial contamination in milk is prevalent, and it is linked to an unsanitary milk supply chain ${ }^{1,2}$. When milk becomes contaminated with bacteria, it spoils quickly and also, could be a source of milk-borne illnesses in humans. Studies reveal that pathogenic bacteria such as Brucella abortus, Escherichia coli 0157: H7, Mycobacterium Bovis, Campylobacter jejuni, Salmonella spp., Clostridium spp., and Staphylococcus aureus cause up to $90 \%$ of all dairy-related disorders $3,4,5$.

\section{Correspondence}

\section{Dr. Rubeena Gul}

Associate Professor.

Department of Community Medicine, Khyber Medical

College, Peshawar - Pakistan

Email: gul_rubeena@yahoo.com

Cell: $+92-301-8965970$

Date received: $22-05-2020$

Date revised: $01-08-2021$

Date accepted: 07-09-2021
Escherichia coli organisms are the most common contaminants of raw and processed milk. ${ }^{6}$ In a study, $65 \%$ of raw milk tested in Malaysian dairy farms were positive for Escherichia coli ${ }^{7}$ whereas $74 \%$ of the samples were contaminated with E Coli in a study in Turkey. ${ }^{8}$ Staphylococcus Aureus due to its ability to produce enterotoxin, is an important cause of milk-borne diseases in humans. Staphylococcus Aureus strains has been isolated from hands of milking persons and dairy cows. A study in Iran in 2015 on 1930 samples of raw cow milk, showed the prevalence of Staphylococcus Aureus as $12.4 \%{ }^{9}$. Salmonella contamination can either be due to infected persons or contamination of environment or by consumption of raw milk or its products ${ }^{10}$. Studies in Rawalpindi and Islamabad revealed that infection with Salmonella were as low as $6 \%$ as compared to other microbes ${ }^{11}$.

Peshawar is one of the major city of Pakistan, having a population of 2,203,000 ${ }^{12}$. Milk for consumption, comes not just from the city's surrounds, but also from the interiors of other districts. Despite having a substantial amount of milk supply, manufacturing, delivery, and storage conditions are all still done in traditional ways. In such circumstances, the possibility of milk-borne illness is a major public concern ${ }^{13}$. Milk, on the other hand, travels through numerous hands from producer to consumer, and as a result, the quality of milk reaching customers is frequently substandard, both from a hygienic and nutritional 
standpoint. There is a scarcity of information on microbial pathogens in milk in Peshawar, therefore, this study was an attempt to perform the microbial analysis of raw cow's milk collected from selling points of Peshawar.

\section{MATERIALS AND METHODS}

A cross-sectional descriptive study was conducted in Peshawar district and laboratory work was done at Agriculture University Peshawar. Multistage sampling technique was adopted where Peshawar was divided into four towns, TW-1 (Town 1, L-1 Sikandar Town, L-2 Gul Bahar ), TW-2 (Town 2, L-3 Shahi Bala, L-3 Pajjagi), TW-3 (Town 3, L-5 University Road, L-6 Hayatabad), TW-4 (Town 4, L-7 Hazar Khawani, L-8 Badaber) samples were collected.

Sample size was calculated according to WHO sample size formula as $n=z^{2} p q / d^{2}$. A total quantity of 80 samples of raw milk were collected at selling points aseptically in sterile glass bottles. The collected samples were shifted to the University of Agriculture Peshawar, Department of Animal health for analysis laboratory for processing on ice packs maintaining $6-8^{\circ} \mathrm{C}$. A total of 20 milk samples were collected twice a week for four weeks. Microbial Analysis of Milk: The total plate count evaluation standard pour plate technique was followed. Tenfold dilution was standardized $1 \mathrm{ml}$ of milk sample to $9 \mathrm{ml}$ of Normal saline solution (NSS). Dilutions were standardized and quantity of $0.1 \mathrm{ml}$ inoculums from $10^{-3}$ and $10^{-4}$ dilutions were processed on pour plate technique and agar was poured and mixed thoroughly by rotating the plates. The plates were incubated for 24 hours at temperature of $37^{\circ} \mathrm{C}$. Total plate counts were calculated by using standard formula ${ }^{17}$.The bacterial colonies were counted with the help of the bacte- riological colony counter (MAC) and colony forming (CFU) was counted by using the formula below.

$$
[\mathrm{n} 1+(0.1 \times \mathrm{n} 2)] \times \mathrm{d}_{\log _{10}} \mathrm{CFU} / \mathrm{gm}=\underline{\sum \mathrm{C}}
$$

Where, $\Sigma \mathrm{C}=$ Total number of colonies counted from all plates, $n 1=$ No. of plates of lower dilution, $n 2=$ No. of plates of higher dilution, $d=$ Dilution factor

Staphylococcus Aureus Count: $1 \mathrm{ml}$ of raw milk were placed for Staphylococcus Aureus, isolation in each decimal dilution and were patterned on the surface of pre solidified (mannitol salt) medium for $37^{\circ} \mathrm{C}$ for 48 hours and colonies were counted on colony counter under microscope expressed and calculated.Salmonella Count: About $25 \mathrm{ml}$ of raw milk were added to $225 \mathrm{ml}$ of sterilized buffered peptone water and incubated at $37^{\circ} \mathrm{C}$ overnight and colonies were counted. Escherichia Coli Count: Dilutions were made by withdrawing $1 \mathrm{ml}$ of raw milk sample into $9 \mathrm{ml}$ of $0.1 \%$ sterilized buffered peptone water and then further serial dilutions. A $10 \mu \mathrm{L}$ was drawn from appropriate dilutions and placed on MacConkey Agar. Spread the sample on agar by sterile glass rod, and plates were incubated at $37^{\circ} \mathrm{C}$ for 24 hours. The colonies were counted. The data were analyzed by Statistical Package for Social Sciences (SPSS) version 20.

\section{RESULTS}

Three bacteria namely Staphylococcus Aureus 13 (16.2\%), E.coli 21 (26.2\%) and Salmonella spp 03 (3.75\%) were isolated and identified in the present study area. Out of 80 samples $37(46.2 \%)$ were contaminated with different bacteria's like $26.2 \%$ was E Coli , $16.2 \%$ was staphylococcus and $3.75 \%$ was salmonella species see table 1 for details. See table 2

Table 1: Frequency of bacteria isolated from milk samples collected from different selling points of Peshawar

\begin{tabular}{|c|c|c|c|c|c|c|c|c|c|}
\hline \multirow[t]{3}{*}{ Bacteria Isolated } & \multicolumn{8}{|c|}{ Bacteria isolated from milk samples } & \multirow[t]{3}{*}{ Total (\%) } \\
\hline & \multicolumn{2}{|c|}{ TW1 } & \multicolumn{2}{|c|}{ TW2 } & \multicolumn{2}{|c|}{ TW3 } & \multicolumn{2}{|c|}{ TW4 } & \\
\hline & $\mathrm{L}-1$ & $\mathrm{~L}-2$ & L-3 & $\mathrm{L}-4$ & L-5 & L-6 & L-7 & $\mathrm{L}-8$ & \\
\hline Staphylococcus & 02 & 01 & 03 & 02 & 0 & 01 & 02 & 02 & $13(16.2 \%)$ \\
\hline E.coli & 03 & 01 & 04 & 01 & 02 & 03 & 05 & 02 & $21(26.2 \%)$ \\
\hline Salmonella spp & 00 & 00 & 01 & 0 & 01 & 00 & 01 & 00 & 03 (3.75\%) \\
\hline Total & 05 & 02 & 08 & 03 & 03 & 04 & 08 & 04 & 37 (46.2\%) \\
\hline
\end{tabular}

TW-1 (Town 1, L-1 Sikandar Town, L-2 Gul Bahar), TW-2 (Town 2, L-3 Shahi Bala, L-3 Pajjagi),

TW-3 (Town 3, L-5 University Road, L-6 Hayatabad), TW-4 (Town 4, L-7 Hazar Khawani, L-8 Badaber)

Table 2: Frequency of bacteria isolated from milk samples collected from different selling points of Peshawar

\begin{tabular}{|c|c|c|c|c|c|c|c|c|c|}
\hline \multirow{2}{*}{$\begin{array}{c}\text { Milk selling } \\
\text { point }\end{array}$} & \multirow{2}{*}{$\begin{array}{l}\text { Positive } \\
\text { samples }\end{array}$} & \multicolumn{3}{|c|}{ Average bacterial count of samples } \\
\cline { 3 - 11 } & & \multicolumn{2}{|c|}{ Total Plate Count } & \multicolumn{2}{|c|}{ Total staph Count } & \multicolumn{2}{|c|}{ Total E. Coli Count } & \multicolumn{2}{c|}{$\begin{array}{c}\text { Total Salmonella } \\
\text { Count }\end{array}$} \\
\cline { 3 - 11 } & & CFU/ml & Log & CFU/ml & Log & CFU/ml & Log & CFU/ml & Log \\
\hline TW-1 & 07 & 660,378 & 5.81 & 508.12 & 2.70 & 243.72 & 2.38 & 115.04 & 2.06 \\
\hline TW-2 & 11 & 540,230 & 5.73 & 430.23 & 2.63 & 205.14 & 2.31 & 125.01 & 2.09 \\
\hline TW-3 & 07 & 620,538 & 5.79 & 460.09 & 2.66 & 228.10 & 2.35 & 109.21 & 2.03 \\
\hline TW-4 & 12 & 756,400 & 5.87 & 538.07 & 2.73 & 271.23 & 2.43 & 121.06 & 2.08 \\
\hline
\end{tabular}

TW-1 (Town 1, L-1 Sikandar Town, L-2 Gul Bahar), TW-2 (Town 2, L-3 Shahi Bala, L-3 Pajjagi),

TW-3 (Town 3, L-5 University Road, L-6 Hayatabad), TW-4 (Town 4, L-7 Hazar Khawani, L-8 Badaber) 


\section{DISCUSSION}

In our study the difference in value of the total viable count might be due to unhygienic practices of milking. The unhygienic condition of the milking methods may cause a high burden of pathogenic bacteria in milk. The bacterial count may be due to environmental condition of barn and malpractice cleanness at the time of milking, storing and transportation enhanced bacterial growth especially salmonella spp from contaminated objects during handling ${ }^{14,15}$.

The improper hygienic condition leads to contamination of milk with high plate count value as reported by different studies in Badin, Pakistan, and studies in Ethopia $^{16,17,18}$. While in my study only salmonella species count was high.

It was reported that high plate count can be subjective of poor storage, faulty milking, hygienic condition of cow barn and milking and storage kits $^{19,20,21,22}$ which were consistent to our findings.

The contamination of each isolated bacteria were higher across the selling points. The level of contamination a study done at Ethopia revealed Staph aureus were higher in collecting points ${ }^{23}$ while our study also had similar contamination.

Another study done at Ethopia also supported our study findings that milk contamination involved unhygienic practices pre milking as udder cleanliness, unhygienic status of milk handlers and post milking involved sanitation of storage tools and contamination during transportation on roadside ${ }^{24}$.

It has been reported in a study in Nigeria that high isolation frequency of Staph aureus (38\%), E.coli (24\%) and Salmonella spp (2\%) from milk at various retails points 25. While our study had low staph aureus and high E Coli and salmoneela spp.

However, it has also been reported that even in hygienic circumstance milk comprises microorganism which may either resulting from milk ducts or additional contamination either may come from milking equipment and milk handlers ${ }^{26}$. Similar, studies conducted in Ethiopia to assess contamination of milk, with a higher frequency of E.coli was observed across market chain ${ }^{17}$.

The isolation of staph aureus, E. coli and salmomella spp pointed out that milk samples indicated risk of enteropathogenic bacteria ${ }^{25,27}$ and same is true in our study. Limitations of my study were no access to dairy farms and financial constrains as the tests were costly.

\section{CONCLUSION}

Although the presence of E.coli spp, staph spp and salmonella spp. indicate that the milk is contaminated due to external sources possibly due to fecal pollution from cows dunk and having public health significance but it was found to be within permissible limit, except for salmonella spp and if not controlled will lead to public health issues. It is recommended that the community awareness might be imitated among the farmers for hygienic milk production and processing. Hygienic practices like hand washing by the milk handlers and pasteurization by the consumers etc are recommended to be applied.

\section{REFERENCES}

1. Lubote R, Shahada F, Matemu A. Prevalence of Salmonella spp. and Escherichia coli in raw milk value chain in Arusha, Tanzania. American J Res Comm. 2014;2(9):1-3.

2. Abebe R, Hatiya H, Abera M, Megersa B, Asmare K. Bovine mastitis: prevalence, risk factors and isolation of Staphylococcus aureus in dairy herds at Hawassa milk shed, South Ethiopia. BMC Veter Res. 2016 Dec;12(1):11.

3. Lozano C, Gharsa H, Ben Slama K, Zarazaga M, Torres C. Staphylococcus aureus in animals and food: methicillin resistance, prevalence and population structure. A review in the African continent. Microorgan. 2016 Mar;4(1):12.

4. De Garine-Wichatitsky M, Caron A, Kock R, Tschopp R, Munyeme M, Hofmeyr M, Michel A. A review of bovine tuberculosis at the wildlife-livestock-human interface in sub-Saharan Africa. Epidem \& Infect. 2013 Jul;141(7):1342-56.

5. Manyi-Loh C, Mamphweli S, Meyer E, Okoh A. Antibiotic use in agriculture and its consequential resistance in environmental sources: potential public health implications. Molecul. 2018 Apr;23(4):795.

6. Meshref AM. Bacteriological quality and safety of raw cow's milk and fresh cream. Slov Veter Res. 2013 Jan 1;50(1):21-30.

7. Shojaei ZA, Yadollahi A. Physicochemical and microbiological quality of raw, pasteurized and UHT milks in shops. Asian J Sci Res. 2008;1(5):532-8.

8. Gundogan N, Avci E. Occurrence and antibiotic resistance of Escherichia coli, Staphylococcus aureus and Bacillus cereus in raw milk and dairy products in Turkey. Inter J dairy tech. 2014 Nov;67(4):562-9

9. Jamali $H$, Paydar M, Radmehr B, Ismail S, Dadrasnia A. Prevalence and antimicrobial resistance of Staphylococcus aureus isolated from raw milk and dairy products. Food Control. 2015 Aug 1;54:383-8.

10. Batool SA, Kalsoom R, Rauf N, Tahir SS, Hussain F. Microbial and physico-chemical quality assessment of the raw and pasteurized milk supplied in the locality of Twin city of Pakistan. Inter J Food Safety. 2012;14:17-22.

11. Lubote R, Shahada F, Matemu A. Prevalence of Salmonella spp and Escherichia coli in raw milk value chain in Arusha, Tanzania. Amer J Res Commun. 2014; 2(9):1-3.

12. www. https://worldpopulationreview.com/countries/cities/pakistan accessed on 20/Oct/2020.

13. EFSA Panel on Biological Hazards (BIOHAZ). Scientific opinion on the public health risks related to the consumption of raw drinking milk. EFSA J. 2015 Jan;13(1):3940. 
14. Kumar V, Arora P, Ibrahim M. Studies on microbiological quality of milk and milk products sold in Allahabad city. Inter J Applied Res 2015; 1(9): 232-234

15. Pudale PS, Deshmukh VV. Microbial Analysis of Buffalo Milk at Various Stages of Supply Chain in and around Parbhani City, India. Int. J. Curr. Microbiol. App. Sci. 2018;7(2):1711-8.

16. Soomro AA, Khaskheli M, Memon MA, Barham GS, Haq IU, Fazlani SN, Khan IA, Lochi GM, Soomro RN. Study on adulteration and composition of milk sold at Badin. Inter J Res Applied, Nat and Soci Sci. 2014;2(9):57-70.

17. Tassew A, Seifu E. Microbial quality of raw cow's milk collected from farmers and dairy cooperatives in Bahir Dar Zuria and Mecha district, Ethiopia. Agriculture and Bio J North America. 2011;2(1):29-33.

18. Gurmessa T. Physicochemical properties and microbial quality of raw cow's milk in yabello district, borana zone, southern Ethiopia (Doctoral dissertation, MSc Thesis, Haramaya University, Haramaya, Ethiopia).

19. Holm, C., Mathiasen, T. and Jesperson, L. A flow cytometric technique for quantification and differentiation of bacteria in bulk tank milk. J Appl Micro. (2004). 97(5): 935-941

20. Hasan, A., Islam, A; Mahmud, M. S., Ashab Uddin, A.S.M. and Ahmed, S. (2015). Microbial analysis of raw and pasteurized milk from selected areas of Dinajpur, Bangladesh. Asian J Med Bio Res. 1(2): 292-296

21. Woldemariam, H.W. and Asres, A.M. Microbial and Physicochemical Qualities of Pasteurized Milk. J Food Process Techn. (2017). 8(1):1-5.

22. Saxena M, Rai P. Microbiological and chemical analysis of raw, pasteurized and UHT milk during preservation in India. Intern J ChemTech Res. 2013;5(6):2804-9.

23. Daka D, Solomon G,Yihdego D. Antibiotic resistance Staphylococcus aureus isolated from cow's milk in the Hawassa area, South Ethiopia. Annals Clin Microbiol Antimicrob 11:26, 2012.
24. Garedew L, Berhanu A, Mengesha D, Tsegay G. Identification of gram-negative bacteria from critical control points of raw and pasteurized cow milk consumed at Gondar town and its suburbs, Ethiopia. BMC Public Health. 2012;12:950.

25. Olatunji EA, Ahmed I, Ijah UJ. Evaluation of microbial qualities of skimmed milk (nono) in Nasarawa State, Nigeria. In Proceeding of the 14th Annual Conf. of Ani. Sc. Asso. of Nig. (ASAN) LAUTECH Ogbomoso 2009 Sep 14.

26. Solomon M, Mulisa M, Yibeltal M, Desalegn G, Simenew. Bacteriological quality of bovine raw milk at selected dairy farms in Debre Zeit town, Ethiopia. Compr J Food Sci Technol Res. 2013;1(1):1-8.

27. Arafa M, Soliman M. Bacteriological Quality and Safety of Raw Cow's Milk and Fresh Cream. Slov Vet Res. 2013;50(1):21-30

CONFLICT OF INTEREST: Authors declare no conflict of interest

GRANT SUPPORT AND FINANCIAL DISCLOSURE: NIL

\section{AUTHOR'S CONTRIBUTION}

Following authors have made substantial contributions to the manuscript as under

Alam A: $\quad$ Concept, data collection, article writing

Akhtar A: Data collection, article writing

Gul R: Data collection, article writing, Data Analysis

Rehman R: Data collection, Referencing

Authors agree to be accountable for all aspects of the work in ensuring that questions related to the accuracy or integrity of any part of the work are appropriately investigated and resolved. 